\title{
My Architectural Credo: The Architecture as Cultural Beginning
}

\author{
Todor Tsigov* \\ Faculty of Architecture, University in Sofia, Bulgaria
}

Submission: May 21, 2018; Published: June 26, 2018

*Corresponding author: Todor Tsigov, Faculty of Architecture, University of Architecture, Civil Engineering and Geodesy, University in Sofia, Bulgaria, Email: tsigov_far@uacg.bg

Keywords: Architectural Credo; Cultural Beginning; Language's transposition; Instinctive relation; Stimulus-reaction; Tectonised; Language's phenomenon

\section{Opinion}

The human perceptions are architectural because of language. When we recognize the object, the sign, the phenomenon by its name we attach to it a meaning of the name. The name's relation image-meaning is the language's transposition of the instinctive relation stimulus-reaction. Therefore, the meaning (corresponding to reaction) contains the behavior's models. Because in nature there are no meanings, the perception of the environment, as the manifestation of meanings, is of the world as a language's phenomenon. The object -percept as an incarnation of its name-becomes, for us, tectonised by the name's meaning i.e. by the related behavior's model. Simultaneously the space around the object is organizing itself around the eventual behavior suggested by the percept's meaning.

Tectonics and space-volumetric organization are the basic architectural categories by which the theory of architecture starts. It turns out that they spring up in the human perception because of language. But language is a beginning of the man. So language transforms the human perceptions into architectural; and architecture itself is a reverse applying in universe the objective laws of architectural perceptions (by treatment of the material according to the meanings).

The origin of architectural i.e. human perceptions is ecological because they derive -by the language's transposition-from the animal ones, having evolved along with all nature and contained (in a hidden way) through experience from the very beginning of life. Since the cultural development and the cultural directions start with the perception, architecture, as a perception's specific, can be a universal cultural tool; not a building activity only.

Architecture in its turn (design also) doesn't exists. It has two incorporable components: the utilitarian and the figurative (the artistic). The utilitarian component is a real manifestation of essence; its material is used really. The figurative component is a conditional manifestation of essence; its material is used conditionally: for the meaning of signs is not a material quality. The architectural form is inexistent because its two components cannot interact objectively. Since the real and the conditional manifestations of essence could do it, that could be magic. The architectural object is actually two incompatible objects in one material and the unique place of them unifying is the human perception, but not the reality. In this way architecture is a myth. Then the person who practices it, the architect-consciously or unconsciously-is a priest.

The independence of the two components of the Architectural Myth allows combining the architectural providing of every human function with the torpedo of arbitrary figurative subject. The person, being unable to separate the utilitarian and figurative components, thinks that he is interacting with all objects. In reality, he interacts only with the utilitarian component. However, his utilitarian interaction turns out as a ritual act toward the figurative component mythologizing its conditional manifestation of essence as reality. Since this mythologization is unconsciously adopted, the behavior conforms itself to the depiction as a reality. That's a suggestive potential of architecture (and design).

In traditional architecture the suggestions of the figurative component follows the collective ecological rooted experience. Through them the harmony with the universe is supported in contrast with the author's architecture. In this way the suggestions from the figurative component of the author's architecture could be risky.

Mythology has been the "natural program space" for architecture since its arising. The historical replacement of 


\section{Civil Engineering Research Journal}

traditional architecture by the author's one runs parallel to the acceleration of the myth-creation. Approximately in the beginning of XX century the myth-creation's speed surmounts the speed of building and the architecture loses its "program space". This is the offset of modern architecture which starts to look for the "architectural languages" and to find them also in the past. However, the "architectural language" is a mistake because of the lack of a "program space". The way out of the contemporary idea's architectural crisis -not with standing the architectural achievements -could be in the substitution of the lost traditional (and next) mythology by the common language as a world mythologized factor preceded the mythology. Actually the traditional mythology is a fixed -by the ancient mythological precedents-mythologization of the world by language. Language gives the primary fluent mythologization (fixed subsequently) and is happening nowadays in every moment of human i.e. architectural perception. So language can be a new architectural "program space", more constant than the accelerated mythology. No "architectural languages" but the common regional languages in architecture.

Regional languages are conforming to the regional conditions of life, the regional ecosystem and the respective habits and tradition. That's why for the most part the buildings must reflect architecturally the regional language. In the modern, mobile and cosmopolite society architecture-as immobilecould be the factor of preservation, development and suggestive reproduction of the immaterial heritage nowadays living in a regional mode of existence. It will suggestively help even the temporary inhabitants with a different identity. In this way the regional and the cosmopolitan tendencies being divided between architecture and people could co-exists without mutual denial according to the effective principle of the Saint Symbol: in-united and in-separable.

\section{Your next submission with Juniper Publishers will reach you the below assets}

- Quality Editorial service

- Swift Peer Review

- Reprints availability

- E-prints Service

- Manuscript Podcast for convenient understanding

- Global attainment for your research

- Manuscript accessibility in different formats

( Pdf, E-pub, Full Text, Audio)

- Unceasing customer service

Track the below URL for one-step submission https://juniperpublishers.com/online-submission.php 